\title{
The effect of natural hazards and disasters for tourism: case studies in the Carpathian Basin
}

\author{
L. David \\ Károly Róbert College, Hungary
}

\begin{abstract}
This paper draws attention to the fact that natural disasters can be very damaging for the tourism industry. The study provides a detailed overview on the possibilities of the mitigations of natural hazards and disasters. Firstly, the River Tisza in Hungary is a very important tourism destination, but, after decades of unusually dry weather periods, the area experienced heavy rainfalls between the years of 1988 and 2002, causing floods of considerable magnitude in the Carpathian Basin and several dangerous flood waves passing down the River. The defence against the raging rivers put an enormous burden on the national budget and yet could not provide satisfactory lines of defence in the end. Therefore, there was an urgent need to solve the problem. This project is the largest and greatest regional development plan ever conceived and implemented in the Carpathian Basin. The rural and regional development opportunities are considerable and the economic and infrastructural improvements will be a challenge for the Hungarian institutions and authorities. Secondly, more and more natural disasters appeared in the Carpathian Basin caused by storms and tempests. Very important tourism destinations, High Tatras in Slovakia, Hungarian and Rumanian mountains, were destroyed by huge natural disasters. To preserve the harmony and balance between the tourism industry and nature, and to defend against disasters, the best strategies can be found based on sustainable tourism and destination planning. The author proposes recommendations to help identify the correct solutions.
\end{abstract}

Keywords: tourism, natural hazards, disasters, Carpathian Basin. 


\section{Introduction}

After decades of unusually dry weather periods the area experienced heavy rainfalls between the years of 1988 and 2002, causing floods of considerable magnitude in the Carpathian Basin and several dangerous flood waves. The defence against the raging rivers put an enormous burden on the national budget and yet could not provide satisfactory lines of defence in the end. Therefore, there was an urgent need to solve the problem. The new Vásárhelyi Plan does intend to provide exactly that, an effective defensive structure in case of flood related emergencies. The so-called new Vásárhelyi Plan (abbreviated in Hungarian as VTT) was accepted by the Hungarian Government in October 2003. It is a plan of great dimensions aiming to provide efficient protection from the recurring flooding in Eastern Hungary. In the first stage of the plan (VTT), six reservoirs will be constructed along the River Tisza to provide enhanced defence against rising waters (Figure 1). During the construction environmental and conservational considerations will also be taken into account. The estimated cost of the VTT totals 130 billion HUF and will be financed from both Hungarian and European Union sources [1].

\section{1/. meltékiet}

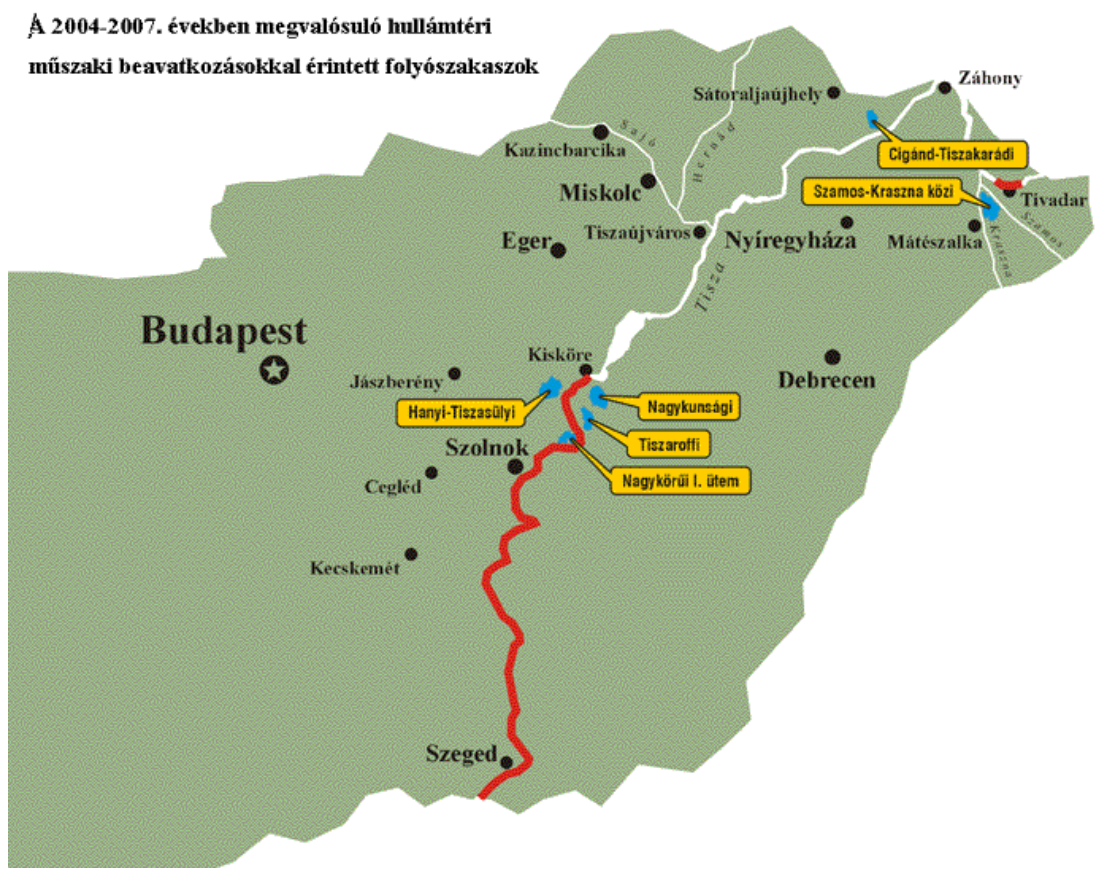

Figure 1: $\quad$ Six reservoirs scheduled for stage I [11]. 
The disasters caused by weather extremities and climate change were examined. For instance, on 19 November 2004, large parts of the forests in the southern part of the High Tatras (TANAP-High Tatras National Park in Slovakia) were damaged by a strong wind storm. Three million cubic metres of trees were uprooted, two people died and several villages were totally cut off. Further damage was done by a subsequent forest fire, and it will take many years until the local ecology is fully recovered. Similar, but smaller events happened in Hungary and Romania last years. Externality of weather damage and climate change may cause negative impacts for tourism (e.g. reduced tourist flows, increased costs).

\section{Solution against floods}

At this stage it should be mentioned that the person after whom the project was named, Pál Vásárhelyi, was a talented, young engineer in the middle of the $19^{\text {th }}$ century, who devised the most ambitious reclamation project ever carried out in Hungary. Thus, his name is associated with the "taming" of the River Tisza.

The present project follows on Vásárhelyi's plans and designs by diverting the excess water to thirty reservoirs being built. The water stored in these reservoirs will then be channelled to the use of new types of agro-ecological farming and environment management.

The main aim of the new VTT is thus to raise the safety of the population and their properties in the one hand and to introduce new water-based cultivation techniques to the area in the other. These novel methods of agricultural production will then, hopefully, bring a much needed extra income and prosperity to the region. The project covers a four-year time-span and will be completed in the near future. Several ministries and research institutions take part in this joint project from the planning stage to the implementation stage. Apart from institutionalized support, the planners made great efforts to secure the approval of the local population through a series of public meetings and consultations.

The European Union's "Water Framework Directive" has also been taken into account in the ecological feasibility studies. Environmental and ecological considerations will be of utmost importance. The project also aims to conserve and enhance the natural beauty of the area while promoting tourist development at the same time. Part of the project is the developing of the area for public enjoyment too, while having regard to the needs of agriculture and forestry and the economical and social interests of those who live and work there. The potential for recreation on land and water in the area is immense. Sailing, rowing, canoeing, fishing, walking, sightseeing and bird watching are just some of the ways local people and visitors could enjoy the area upon completing the project. The creation of the so-called Tisza Riparian Ecoregion will then have five major purposes (Figure 2):

- Flood Control

- Rural development

- Agro-ecological farming 


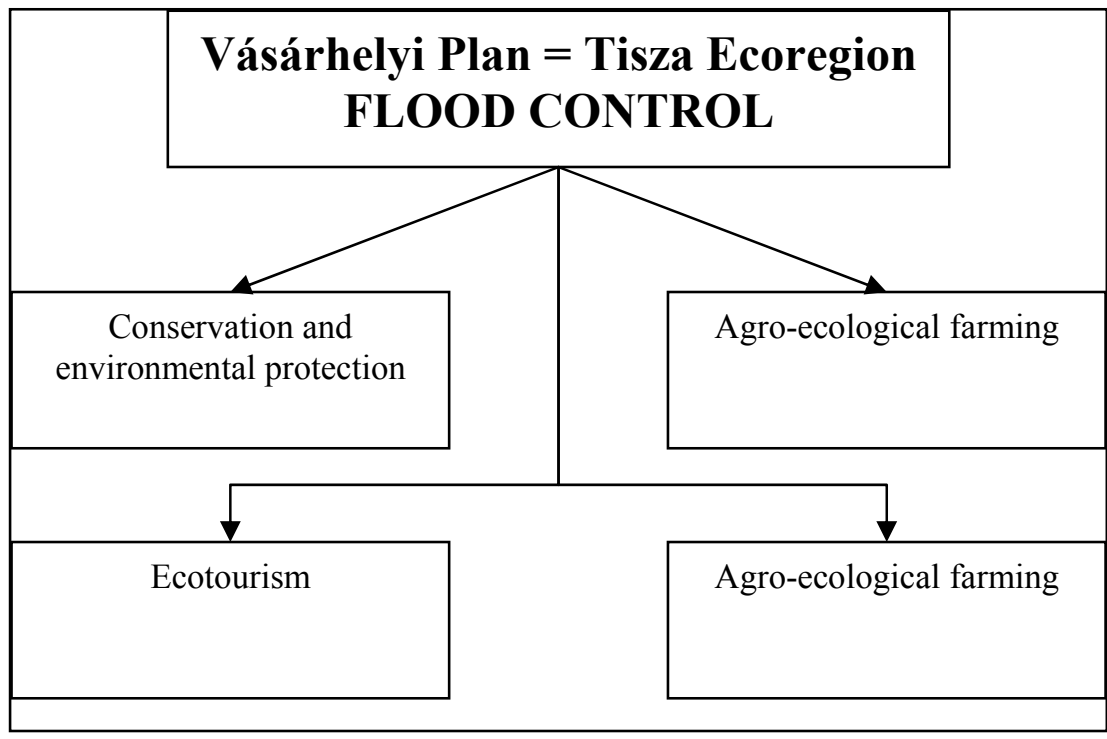

Figure 2: $\quad$ A complex project $=$ Tisza Riparian Ecoregion [11].

- Tourism (ecotourism)

- Conservation and environmental protection

\section{The magnitude, importance and present situation of the VTT project}

This project is the largest and greatest regional development plan ever conceived and implemented in the Carpathian Basin. The rural and regional development opportunities are considerable and the economic and infrastructural improvements will be a challenge for the Hungarian institutions and authorities. There has been a series of political, public and professional forums and debates and such consultations will have to be continued throughout the life of the project. We hope that the end result will be the rebirth of the River Tisza and the surrounding areas. There should be novel land use patterns in place and tourism will play an ever-increasing role in the revitalization of the hitherto rather poor rural region. The spirit of the new Vásárhelyi Plan will continue the visionary work of those $19^{\text {th }}$ century engineers who contributed so much for the viability of human existence and activities along the River Tisza. However, this project is a huge challenge for the tourism experts, and means a lot of opportunities of the water and lake tourism development.

Unfortunately the present results of the first stage of the New Vásárhelyi Plan has not been finalised yet. Instead of the planned 6 reservoirs only 2 were finished at Cigánd-Tiszakarád (2008) and Tiszaroff (2009). And other works are in progress at more than 20 spots in the flood plain. The main cause of the lag is the lack of money: the government could spend 25 billion HUF on the 
implementation instead of the planned 130 billion HUF. The government intended to modify the law of Vásárhelyi Plan, accordingly from this the implementation will be financed by sources of the European Union, and the second stage will last to 2025 instead of 2013 . We hope that at the end of the project the goals will be realized as soon as possible.

\section{Solution against storms}

The declaration of International Workshop Policy Options for Storm Damage Management (18-21 April 2005, Zvolen, Slovak Republic) recommended the following $[9,10]$ :

- to base decisions on economically viable development elaborated by competent authorities on the priority protection of natural and cultural heritage, respecting the law and ownership rights, using participatory processes of consensus building,

- To use a participatory approach, improve communication and build trust, involving representatives of all stakeholders and the public in general into technical, administrative and financial storm damage management measures as well as into general policy decision making on forest land use in Slovakia,

- To complement urgently the existing storm damage analyses by a risk scenario assessment, considering all environmental, social and economic functions of forests and forestry (such as erosion, biodiversity, water management, rural development etc.) and assure public access to storm relevant information,

- To focus the overall storm damage management carried out by various stakeholder groups on maintaining the forest cover and concrete acreage of the forest fund, re-establishing the environmental, social and economic functions of forest land use defined by the existing policy framework,

- To safeguard during decision making about the affected forest area (where so far no consensus could be reached) that the conservation of natural resources have priority over other development interests in the area of the national park, thus leave damaged trees untouched in protection "level 5",

- To not use chemical protection measures by air plane in the area of the TANAP,

- To use close-to-nature forestry measures in TANAP National Park during harvesting, protection measures (pheromone traps, debarking in forest stands) and afforestation (focus on natural regeneration and succession, mixed stands from autochthon tree species),

- The Ministry of Environment and the Ministry of Agriculture to approve a consensus approach for the common procedure to create a zoning plan for all National Parks of Slovak Republic on the base the law Act no. 543/2002 on nature and landscape protection of Slovak Republic,

- As a scientific base to elaborate and implement a comprehensive, long-term "Strategy for Forest Land Use", considering the whole spectrum of societal demands (forestry, biodiversity, water management, landscape protection, 
eco-tourism and rural development, etc), including a review of protected forest zones, provide this strategy as an input to any spatial and territorial planning for Tatra National Park,

- To elaborate and implement restructuring measures for Tatra forests (inline with the "Strategy for Forest Land Use") towards more stable and nature oriented stands, considering the specific climatic circumstances on Southern slopes of Tatra mountains, promote applied research for nature oriented forestry management,

- To monitor the market mechanisms with regard to the stability of roundwood prices as well as the availability of capacities for storm damage management measures (harvesting, protection, planting, others) and undertake if required adequate policy measures (e.g. promote stocks of roundwood and wood products),

- To set up efficient (as less as possible, as much as required) and fair policy framework for all forest owners (state, private, community) which treats all types of ownership equally, implementing compensation measures for nonstate forest owners, exchanging or buying up the land; in line with this to request the Government of Slovak Republic to create a system of reimbursement for losses of all forest owners caused by the implementation of the nature and landscape protection legislation,

- To develop coordination mechanisms for the effective implementation of forest land use management, financial incentives, and other policy measures related to forest land use particularly with regard to nature conservation priority, bundle the corresponding policy institutions and instruments,

- To develop immediately a methodology on the impacts of hazards resulting from the current wind blow on the basis of a consensus of experts,

- To request the government of Slovak Republic to establish a regional hazard assessment and monitoring network with international support in order to gather and disseminate relevant knowledge on hazards relevant to the region and to improve assessment of hazards and the monitoring of their effects,

- To propose to the government to elaborate an umbrella legislation for discussion and agreement to deal more effectively with disaster related issues,

- To continue in consultation process between Ministry of Agriculture and Ministry of Environment and NGOs in order to reach the consensus on the management of Natura 2000 sites [9, 10].

\section{Conclusions}

In the past few decades, interest in the environment has reached a peak as the public has become aware of the extent of the human impact on physical systems. The governments, providers and tourism industry associations in the affected regions, as well as the individual businesses, worked quickly to encourage organisations to help - pointing out that the tourism industry is essential to the livelihoods of large parts of the population in these areas. From a tourism perspective most of the focus has been on encouraging people to continue to 
travel to areas not devastated by the floods and storms in the affected regions in order, so far as possible, to ensure the maintenance of tourism earnings. The mainstream tourism is likely to recover quickly because the formal industry carries various levels of insurance and will largely be able to raise funds for the reconstruction of hotels and resorts.

\section{References}

[1] Dávid, L.-Nagy, Zs.-Gergely, S. (2007): New Vásárhelyi Plan - Reservoirs for tourism along River Tisza in Hungary, pp. 34-41., In: Németh, Á.Dávid, L. eds. 2007: Handbook of Lakes and Reservoirs - a Sustainable Vision of Tourism, Handbooks of Water-based Tourism, Volume 1, Department of Tourism and Regional Development, Károly Róbert College, Gyöngyös, 146p.

[2] Edington, J.M.-Edington, M.A. (1986): Ecology, Recreation and Tourism, Cambridge: Cambridge University Press, 198p.

[3] Michalkó, G. (2003): Tourism eclipsed by crime: The vulnerability of foreign tourist in Hungary, Journal of Travel and Tourism Marketing 15. 23., pp. 159-172.

[4] Michalkó, G. (2006): Tourism, In: Kocsis K. (ed.) South-Eastern Europe in maps, 2nd revised and expanded edition, Geographical Research Institute, Budapest, pp. 126-130.

[5] Newsome, D.-Moore, S.A.-Dowling, R.K. (2002): Natural Area Tourism Ecology, Impacts and Management, Channel View Publications, ClevedonBuffalo-Toronto-Sydney, 340p.

[6] Puczkó, L.-Rátz, T. (2002): The Impacts of Tourism - An Introduction, Häme Polytechnic, Finland, 406p.

[7] Puczkó, L.-Rátz, T. (2005): A turizmus hatásai (The Impacts of Tourism), Aula Kiadó, Budapest, 490p.

[8] Remenyik, B-Bujdosó, Z. (2009): Régiók és határok a turizmusfejlesztésben (Regions and Borders in Tourism Development), In: Gulyás, I. ed. 2009: Jelenkori társadalmi és gazdasági folyamatok (Recent Processes of Society and Economy), 2009./4. (in print) Internet:

[9] http://www.fao.org/regional/seur/zvolen/zvolen1_en.htm

[10] http://www.fao.org/regional/seur/events/Zvolen/docs/recfin.pdf

[11] www.vizugy.hu 